\title{
Correlation of MMP-9 and p53 protein expression with prognosis in metastatic spinal tumor of lung cancer
}

\author{
SHUQUAN ZHANG ${ }^{1}$, MINFEI WU ${ }^{2}$, YI ZHAO ${ }^{3}$, RUI GU$^{4}$, CHUANGANG PENG $^{2}$, \\ JIABEI LIU ${ }^{4}$, QINGSAN ZHU ${ }^{4}$ and $\mathrm{YE} \mathrm{LI}^{4}$ \\ ${ }^{1}$ Department of Orthopedics, Tianjin Nankai Hospital, Tianjin 300100; ${ }^{2}$ Department of Orthopedics, \\ The Second Hospital of Jilin University, Changchun, Jilin 130041; ${ }^{3}$ Department of Surgery, \\ Peking Union Medical College Hospital, Beijing 100032; ${ }^{4}$ Department of Orthopedics, \\ China-Japan Union Hospital of Jilin University, Changchun, Jilin 130033, P.R. China
}

Received March 16, 2017; Accepted July 21, 2017

DOI: $10.3892 / 01.2017 .6887$

\begin{abstract}
The aim of the study was to compare the protein expression of MMP-9 and p53 and examine their correlation with prognosis in lung cancer metastatic spinal tumor. Tissue samples were obtained from 30 cases of para-cancerous tissue (group I), 75 cases of non-metastatic lung cancer tissue (group II) and 100 cases of metastatic spinal tumor tissue of lung cancer (group III). The protein expression of MMP-9 and p53 was detected by immunohistochemistry and was present in all three groups. The positive rate for MMP-9 was 20,67 and $83 \%$, respectively. There was a significant difference among the three groups $(\mathrm{p}<0.05)$. The positive rate for $\mathrm{p} 53$ was $16.7,78.7$ and $92 \%$, respectively. There was a highly significant difference among the three groups $(\mathrm{p}<0.01)$. There was a positive correlation between the protein expressions of MMP-9 and p53 (Spearman's correlation coefficient $r=0.351, p<0.05$ ). The positive or negative expression of the two proteins was statistically significant $(\mathrm{p}<0.05)$ for 5 -year survival. The expression of MMP-9 and p53 proteins in metastatic spinal tumors of lung cancer showed increasing trends, and the expression of MMP-9 and p53 proteins was significantly higher compared to non-metastatic lung cancer tissue and para-cancerous tissue samples. This likely was associated with the invasion and metastasis of lung cancer to the spine. Survival analysis suggested that the overexpression of p53 and MMP-9 were correlated with poor prognosis.
\end{abstract}

\section{Introduction}

It has been reported that spinal tumor cases account for 5\% of all primary bone tumors. They are divided into primary

Correspondence to: Dr Rui Gu, Department of Orthopedics, China-Japan Union Hospital of Jilin University, 126 Xiantai Street, Changchun, Jilin 130033, P.R. China

E-mail:642403512@qq.com

Key words: MMP-9, p53, metastatic spinal tumor of lung cancer, immunohistochemistry, prognosis and metastatic based on tumor origin, with the latter being more common. The primary lesion of metastatic spinal tumor is usually derived from lung, breast and prostate cancer (1-3). Matrix metalloproteinases (MMPs), a proteolytic enzyme family, are involved in the degradation of extracellular matrix (ECM) and promote the metastasis of tumor cells to various peripheral tissues. Most published studies have reported that p53 gene mutation is associated with the formation and development of many human tumors, and its abnormal expression leads to abnormal cell proliferation and causes tumor formation and development (4-8).

Due to the particularity of the spinal tumor anatomical location, spinal tumor tissue invasion and metastasis directly damage the patient's vertebral and paraspinal tissue structure, causing neurological dysfunction in cancer patients. Recent studies have shown that the p53 and MMP-9 proteins are associated with the occurrence, development and invasion of tumor cells $(5,6)$.

The aim of this study was to investigate whether the expression of $\mathrm{p} 53$ and MMP-9 proteins was associated with metastatic spinal tumor of lung cancer and examine its effect on patient prognosis. This study provides new ideas for the prevention of tumor cell metastasis in the human body.

\section{Materials and methods}

\section{Materials}

Experimental materials. In total, 100 tissue samples were obtained from metastatic spinal tumor tissue of lung cancer, 75 samples were obtained from non-metastatic lung cancer tissue and 30 cases were obtained from para-cancerous tissue. All the samples were pathologically diagnosed and all tissues were paraffin-embedded and sectioned continuously $(4 \mu \mathrm{m})$.

Main reagents. Rabbit anti-human MMP-9 monoclonal antibody (Beijing Dingguo Changsheng Biotechnology Co. Ltd., Beijing, China), rabbit anti-human p53 monoclonal antibody (BD Biosciences, Franklin Lakes, NJ, USA), DAB chromogenic agent (Shanghai Haoran Biotechnology Co., Ltd., Shanghai, China), citrate buffer powder (Shanghai Haoran Biotechnology Co., Ltd.), hematoxylin (Shanghai Rongbai Biological Technology Co., Ltd., Shanghai, China) and eosin 
Table I. Tissue MMP-9 protein expression.

\begin{tabular}{|c|c|c|c|c|c|c|}
\hline \multirow[b]{2}{*}{ Groups } & \multirow[b]{2}{*}{ Samples } & \multicolumn{2}{|c|}{ MMP-9 protein } & \multirow[b]{2}{*}{ Positive rate (\%) } & \multirow[b]{2}{*}{$\chi^{2}$} & \multirow[b]{2}{*}{ P-value } \\
\hline & & + & - & & & \\
\hline Para-cancerous tissue (I) & 30 & 6 & 24 & 20 & 29.35 & $<0.05$ \\
\hline $\begin{array}{l}\text { Non-metastatic lung } \\
\text { cancer tissue (II) }\end{array}$ & 75 & 50 & 25 & $67^{\mathrm{a}, \mathrm{c}}$ & & \\
\hline $\begin{array}{l}\text { Lung cancer metastatic } \\
\text { spinal tumor tissue (III) }\end{array}$ & 100 & 83 & 17 & $83^{\mathrm{b}}$ & & \\
\hline
\end{tabular}

Pairwise comparison of positive rate among groups: ${ }^{\mathrm{a} C o m p a r e d ~ w i t h ~ g r o u p ~(I) ~} \chi^{2}=13.65, \mathrm{p}<0.05$; ${ }^{\mathrm{b}}$ compared with group (II) $\chi^{2}=5.34$, $\mathrm{p}<0.05$; ${ }^{c}$ compared with group (III) $\chi^{2}=35.27, \mathrm{p}<0.05$. MMP-9, matrix metalloproteinase-9.

(Shanghai Rongbai Biotechnology Co., Ltd.) were used for immunohistochemistry.

\section{Experimental methods}

Hematoxylin and eosin $(H \& E)$ staining. Paraffin-embedded tissue sections were deparaffinized and washed with ethanol. The sections were thoroughly hydrated and stained with hematoxylin for $10 \mathrm{~min}$ and then washed with $\mathrm{H}_{2} \mathrm{O}$. The sections were differentiated with $1 \%$ hydrochloric acid alcohol for $3 \mathrm{sec}$, washed and then placed in saturated lithium carbonate for $3 \mathrm{sec}$ until a blue color was observed. After the sections were rinsed with running water for $20 \mathrm{~min}$, they were dipped in $1 \%$ alcohol soluble eosin for $10 \mathrm{sec}$ followed by routine dehydration, transparency and mounting.

Immunohistochemical staining. Immunohistochemical staining was used in this study using the following protocol: i) Paraffin-embedded tissue sections were heated at $60^{\circ} \mathrm{C}$ for $2 \mathrm{~h}$ and then deparaffinized and rehydrated with ethanol; ii) for antigen retrieval, the sections were inserted into an iron frame and placed in a tin box full of citric acid. The tin box was heated until the citric acid solution reached boiling point, the voltage was lowered to maintain a rolling boil for $7 \mathrm{~min}$, and then the solution was allowed to cool; iii) one drop of $\mathrm{H}_{2} \mathrm{O}_{2}$ solution was added and then washed out after $10 \mathrm{~min}$; iv) sections were incubated with serum for $10 \mathrm{~min}$; v) sections were incubated with primary antibody for $10 \mathrm{~min}$ and then washed with water 3 times; vi) sections were incubated with secondary antibody for $10 \mathrm{~min}$ and then washed 3 times; vii) streptomycin-biotin-peroxidase was added to the sections and washed 3 times after a $10 \mathrm{~min}$ incubation; viii) fresh DAB was added to sections, which were placed in a dark room; and ix) sections were washed, counterstained, mounted and observed.

Evaluation of experimental results. One hundred cells were counted in a randomly selected visual field, with the average number of cells in the visual field calculated as the number of positive cells expressing the corresponding protein within the tissue. For the coloring score scale, 0-2 points represented no coloring, weak coloring and strong coloring, respectively. The positive rate of stained cells and scores: 1-4 points represented the percentage of positive cells 1-25, 26-50, 51-75 and $76-100 \%$, respectively. The two scores were multiplied, with a final score of 1-2 points indicating a negative expression and a score of 3-8 points indicating a positive expression.
Statistical analysis. Data were analyzed with SPSS 17.0 (Beijing Xinmei Jiahong Technology Co., Ltd., Beijing, China). The differences in the positive rate between groups were analyzed with a $\chi^{2}$ test. The Spearman test was used to analyze the correlation between two proteins. GraphPad Prism 5 was used to analyze the survival rate. $\mathrm{P}<0.05$ was considered to indicate a statistically significant difference.

\section{Results}

Expression of MMP-9 protein. The results showed that MMP-9 protein was almost absent in para-cancerous tissue and present in non-metastatic lung cancer tissue. By contrast, there was a large amount of MMP-9 protein expressed in metastatic spinal tumor tissue (Fig. 1).

The positive rate of MMP-9 protein was $20 \%$ in 6 of the 30 para-cancerous tissue samples. Fifty of the 75 non-metastatic lung cancer tissue samples expressed MMP-9 protein (positive rate $67 \%$ ). In 100 lung cancer metastatic spinal tumor tissue samples, 83 showed positive staining for MMP-9 protein.

The positive rates for MMP-9 protein expression in metastatic spinal tumor tissue and non-metastatic lung cancer tissue were significantly higher than that in para-cancerous tissue and the difference was statistically significant $(\mathrm{p}<0.05)$ (Table I).

Expression of 533 protein. The results showed that $\mathrm{p} 53$ protein was expressed in para-cancerous tissue and this expression was increased in non-metastatic lung cancer tissue. In contrast, there was a large amount of p53 protein expressed in metastatic spinal tumor tissue (Fig. 2).

The positive rate for p53 protein was $16.7 \%$, with 5 positives out of 30 para-cancerous tissue samples. Fifty-nine of the 75 non-metastatic lung cancer tissue samples expressed the p53 protein (positive rate $78.7 \%$ ). Of 100 lung cancer metastatic spinal tumor tissue samples, 92 were positive for p53 protein expression.

The positive expression rate for p53 protein in metastatic spine tumor tissue and non-metastatic lung cancer tissue was significantly higher than that in para-cancerous tissue. The positive expression rate between groups was compared and difference was statistically significant $(\mathrm{p}<0.01)$ (Table II).

Correlation of MMP-9 and p53 protein expression levels in metastatic spinal tumor of lung cancer. There were 

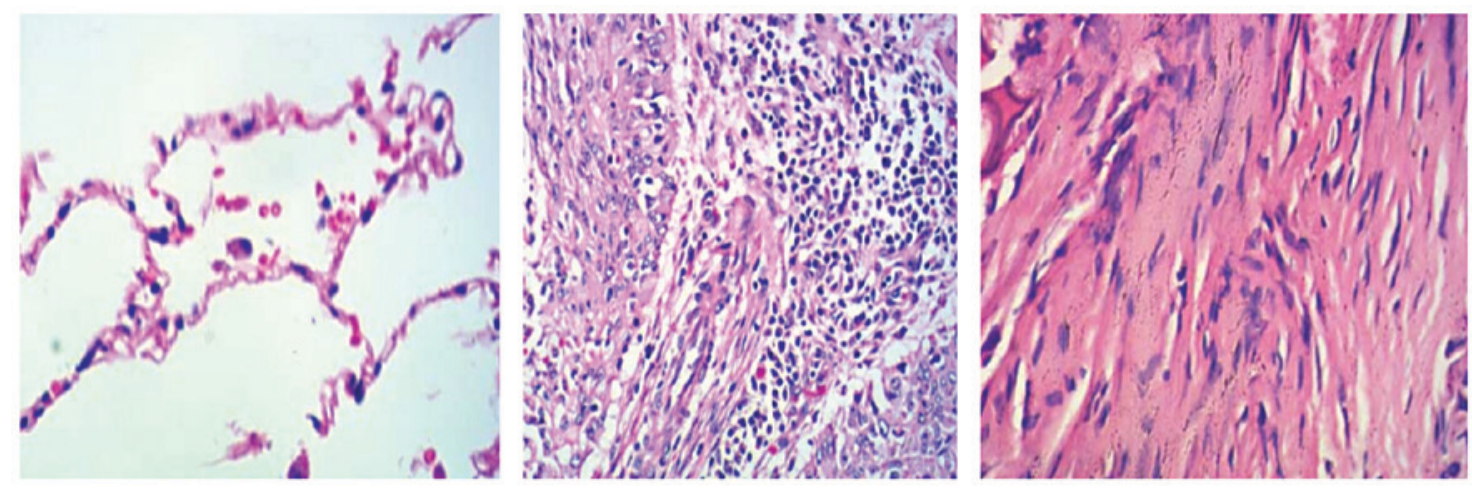

Figure 1. Expression of MMP-9 protein in the three experimental groups (from left to right: para-cancerous tissue, non-metastatic lung cancer tissue and lung cancer metastatic spinal tumor tissue). Samples obtained from para-cancerous tissue, non-metastatic lung cancer and lung cancer metastatic spinal tumor tissue were stained using H\&E staining method. MMP-9 protein was almost absent in para-cancerous tissue, but present in non-metastatic lung cancer tissue and abundantly expressed in metastatic spinal tumor tissue. MMP-9, matrix metalloproteinase-9.
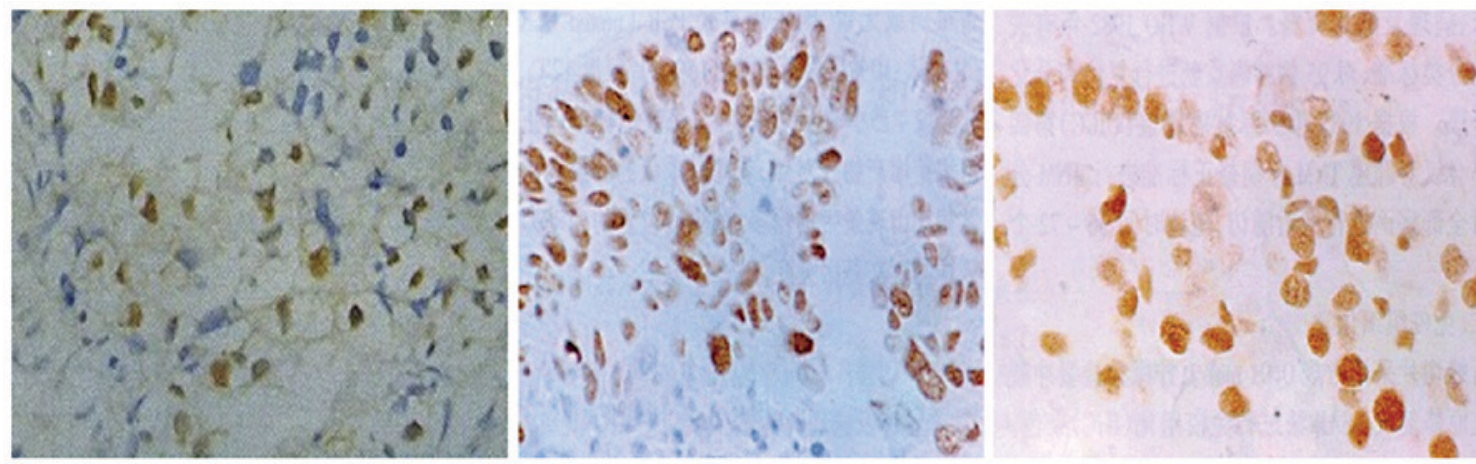

Figure 2. H\&E staining of p53 protein in the three experimental groups (from left to right: para-cancerous tissue, non-metastatic lung cancer tissue and lung cancer metastatic spinal tumor tissue). Samples obtained from para-cancerous tissue, non-metastatic lung cancer tissue and lung cancer metastatic spinal tumor tissue were stained using $\mathrm{H} \& \mathrm{E}$ staining method. There was $\mathrm{p} 53$ protein expression in para-cancerous tissue, increased expression in non-metastatic lung cancer tissues and abundant expression in metastatic spinal tumor tissue.

A

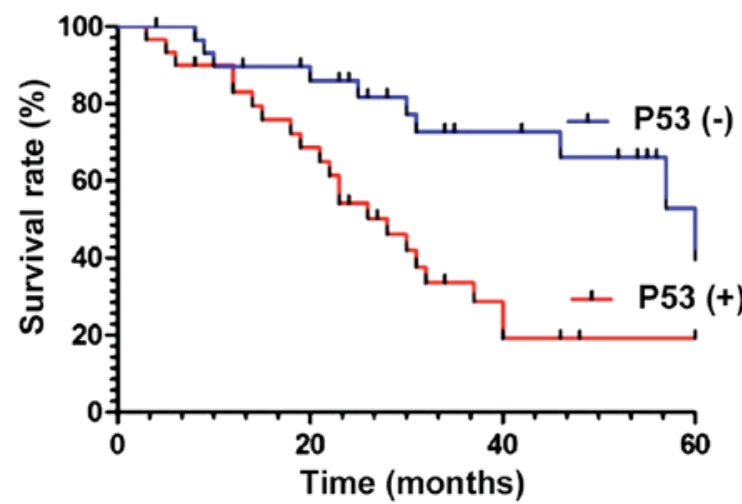

B

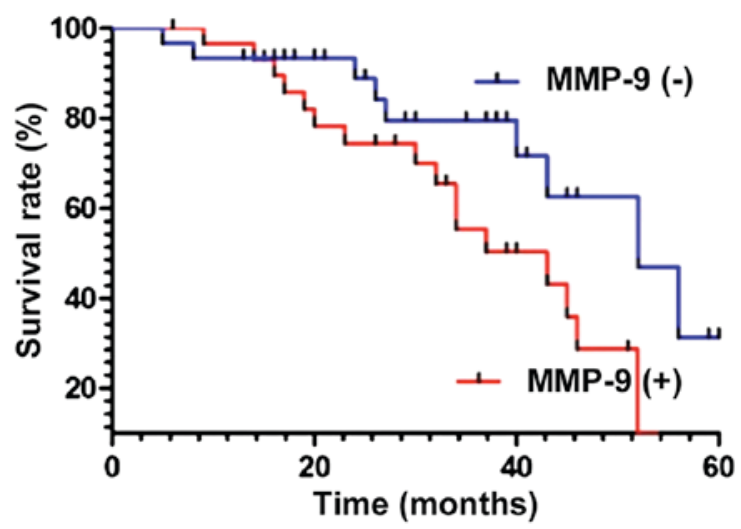

Figure 3. Patient survival curves for MMP-9 and $\mathrm{p} 53$ protein expression positive and negative groups. (A) The survival rate of patients with negative p53 protein expression was significantly higher than that of patients with a positive $\mathrm{p} 53$ expression $\left(\chi^{2}=9.826, p<0.01\right)$. (B) The survival rate of patients with a negative MMP-9 protein expression was higher than that of MMP-9 protein-positive patients $\left(\chi^{2}=4.436, \mathrm{p}<0.05\right)$. MMP-9, matrix metalloproteinase-9.

92 lung cancer metastatic tumor samples presenting positive 53 expression. Of these, 80 showed a positive expression of MMP-9 protein (double positive rate, $87 \%$ ). The expression of the two proteins showed a positive correlation (Spearman correlation coefficient $r=0.351, p<0.05$ ) (Table III).
Association of MMP-9 and 553 protein expression with metastatic spinal tumor of lung cancer patient prognosis. Survival rates in patients with a positive or negative p53 expression were compared during follow-up and analyzed using statistical software. The results showed that the survival rate of patients with 
Table II. p53 protein expression in three tissue sample groups.

\begin{tabular}{|c|c|c|c|c|c|c|}
\hline \multirow[b]{2}{*}{ Groups } & \multirow[b]{2}{*}{ Samples } & \multicolumn{2}{|c|}{ p53 protein } & \multirow[b]{2}{*}{ Positive rate $(\%)$} & \multirow[b]{2}{*}{$\chi^{2}$} & \multirow[b]{2}{*}{ P-value } \\
\hline & & + & - & & & \\
\hline Para-cancerous tissue (I) & 30 & 5 & 25 & 16.7 & 34.28 & $<0.01$ \\
\hline $\begin{array}{l}\text { Non-metastatic lung } \\
\text { cancer tissue (II) }\end{array}$ & 75 & 59 & 13 & $78.7^{\mathrm{a}, \mathrm{c}}$ & & \\
\hline $\begin{array}{l}\text { Lung cancer metastatic } \\
\text { spinal tumor tissue (III) }\end{array}$ & 100 & 92 & 8 & $92^{b}$ & & \\
\hline
\end{tabular}

Pairwise comparison of positive rate among groups: ${ }^{\mathrm{a} C o m p a r e d ~ w i t h ~ g r o u p ~(I) ~} \chi^{2}=13.65$, $\mathrm{p}<0.05$; ${ }^{\mathrm{b}}$ compared with group (II) $\chi^{2}=5.34$, $\mathrm{p}<0.05$; ${ }^{c}$ compared with group (III) $\chi^{2}=35.27, \mathrm{p}<0.05$.

Table III. Correlation of MMP-9 and p53 protein expression in lung cancer metastatic spinal tumor tissues.

\begin{tabular}{lrrrcr}
\hline & \multicolumn{2}{c}{$\mathrm{p} 53$} & & & \\
MMP-9 & + & - & Sum & (Spearman) & P-value \\
\cline { 2 - 5 }+ & 80 & 3 & 83 & 0.351 & 0.028 \\
- & 12 & 5 & 17 & & \\
Sum & 92 & 8 & 100 & & \\
\hline
\end{tabular}

MMP-9, matrix metalloproteinase-9.

negative p53 expression was higher than that of patients with a positive expression of $\mathrm{p} 53$ protein $\left(\chi^{2}=9.826, \mathrm{p}<0.01\right)$ (Fig. $\left.3 \mathrm{~A}\right)$. Similarly, the survival rate of patients with negative expression of MMP-9 protein was higher than that of patients with positive MMP-9 expression $\left(\chi^{2}=4.436, \mathrm{p}<0.05\right)$ (Fig. 3B).

\section{Discussion}

The spine is the most common bone metastatic site for human tumor cells, with $60-85 \%$ of cancer patients showing symptoms of bone metastases. During the bone metastasis process, many changes in gene and protein expression occur. For instance, MMP-9 and p53 are two cancer-related genes which likely play important roles in tumor metastasis (9-13), but their interactions need to be further elucidated.

In tumor cells, MMP-9 is usually produced in the form of zymogen. Its main function is to degrade type-IV and $-\mathrm{V}$ collagen in the ECM, thus aiding tumor cell metastasis, improving capillary endothelial cell regeneration and neovascularization, and promoting tumor cell in vivo occurrence and development.

At present, it has been found that $p 53$ gene is the most closely related gene in tumorigenesis and development, and encodes p53 protein. Kornblum et al (14) found that p53 gene mutations are the most significant genetic change during lung cancer and play a crucial role in the occurrence and development of lung cancer. At the same time, it was also found that tumors with $p 53$ gene abnormalities presented the strongest invasiveness and poorest prognosis.
Immunohistochemical staining was used in this study, with the results showing MMP-9 protein positive expression rate of $20 \%$ in para-cancerous tissue, $67 \%$ in non-metastatic lung cancer tissue and $83 \%$ in metastatic spinal tumor tissue of lung cancer $(\mathrm{p}<0.05)$. Therefore, MMP-9 protein expression can be used as an indicator for predicting the degree of malignancy and prognosis.

The positive or negative expression of MMP-9 and p53 proteins was statistically significant during the survival time $(\mathrm{p}<0.05)$. The positive expression rate of p53 was $16.7 \%$ in para-cancerous tissue, $78.7 \%$ in non-metastatic lung cancer tissue and $92 \%$ in metastatic tumor tissue of lung cancer $(\mathrm{p}<0.01)$. There was a positive correlation between the expression of MMP-9 and p53 proteins $(\mathrm{p}<0.05)$, suggesting that the two proteins likely played a synergistic role in the development and progression of lung cancer metastatic spinal tumor, with the oncogene p53 (wild-type) likely regulating the expression of MMP-9 through negative feedback.

It has been reported widely (15-18) that the $\mathrm{p} 53$ protein was expressed in a number of tumor cells. Previous evidence suggested (19) that the p53 protein had no correlation with the age and survival of patients, and that it was impossible to confirm a correlation between $\mathrm{p} 53$ protein expression and prognosis. It has also been suggested indicated that an enhanced MMP-9 protein expression had a clear positive correlation with the growth, development and metastasis of breast cancer, non-small cell lung cancer, and pancreatic cancer $(1,5,20)$. One of the conclusions of this study further supports the point of view that the expression of this protein in lung cancer metastatic spinal tumor may also have a corresponding function.

In the present study, MMP-9 and p53 protein expression were positively correlated. In addition, the positive or negative expression of MMP-9 correlated with 5-year survival. Further studies regarding the correlation between MMP-9 and p53 expression in tumor cells will be useful to clarify the development and treatment of metastatic spinal tumor in lung cancer.

\section{References}

1. Wang $\mathrm{N}$ and Stamenovic D: Mechanics of vimentin intermediate filaments. J Muscle Res Cell Motil 23: 535-540, 2002.

2. Ulirsch J, Fan C, Knafl G, Wu MJ, Coleman B, Perou CM and Swift-Scanlan T: Vimentin DNA methylation predicts survival in breast cancer. Breast Cancer Res Treat 137: 383-396, 2013. 
3. Kidd ME, Shumaker DK and Ridge KM: The role of vimentin intermediate filaments in the progression of lung cancer. Am J Respir Cell Mol Biol 50: 1-6, 2014.

4. Otsuki S, Inokuchi M, Enjoji M, Ishikawa T, Takagi Y, Kato K, Yamada H, Kojima K and Sugihara K: Vimentin expression is associated with decreased survival in gastric cancer. Oncol Rep 25: 1235-1242, 2011.

5. Schveigert D, Valuckas KP, Kovalcis V, Ulys A, Chvatovic G and Didziapetriene J: Significance of MMP-9 expression and MMP-9 polymorphism in prostate cancer. Tumori 99: 523-529, 2013.

6. Schveigert D, Cicenas S, Bruzas S, Samalavicius NE, Gudleviciene Z and Didziapetriene J: The value of MMP-9 for breast and non-small cell lung cancer patients' survival. Adv Med Sci 58: 73-82, 2013.

7. Ureshino RP, Bertoncini CR, Fernandes MJ, Abdalla FM, Porto CS, Hsu YT, Lopes GS and Smaili SS: Alterations in calcium signaling and a decrease in Bcl-2 expression: Possible correlation with apoptosis in aged striatum. J Neurosci Res 88: 438-447, 2010

8. Chernyatina AA, Nicolet S, Aebi U, Herrmann H and Strelkov SV: Atomic structure of the vimentin central $\alpha$-helical domain and its implications for intermediate filament assembly. Proc Natl Acad Sci USA 109: 13620-13625, 2012.

9. Czabotar PE, Lessene G, Strasser A and Adams JM: Control of apoptosis by the BCL-2 protein family: Implications for physiology and therapy. Nat Rev Mol Cell Biol 15: 49-63, 2014.

10. Gregory MS, Repp AC, Holhbaum AM, Saff RR Marshak-Rothstein A and Ksander BR: Membrane Fas ligand activates innate immunity and terminates ocular immune privilege. J Immunol 169: 2727-2735, 2002.

11. Alecu M, Coman G and Dănăilă L: High levels of sFas and PBMC apoptosis before and after excision of malignant melanoma - case report. Roum Arch Microbiol Immunol 61: 267-273, 2002.
12. Huang SC, Tang MJ, Hsu KF, Cheng YM and Chou CY: Fas and its ligand, caspases, and bcl-2 expression in gonadotropinreleasing hormone agonist-treated uterine leiomyoma. J Clin Endocrinol Metab 87: 4580-4586, 2002.

13. Metser U, Lerman H, Blank A, Lievshitz G, Bokstein F and Even-Sapir E: Malignant involvement of the spine: Assessment by 18F-FDG PET/CT. J Nucl Med 45: 279-284, 2004.

14. Kornblum MB, Wesolowski DP, Fischgrund JS and Herkowitz HN: Computed tomography-guided biopsy of the spine. A review of 103 patients. Spine 23: 81-85, 1998.

15. Sucu HK, Ciçek C, Rezanko T, Bezircioğlu H, Erşahin Y, Tunakan $M$ and Minoğlu M: Percutaneous computedtomography-guided biopsy of the spine: 229 procedures. Joint Bone Spine 73: 532-537, 2006

16. Rades D, Dunst J and Schild SE: The first score predicting overall survival in patients with metastatic spinal cord compression. Cancer 112: 157-161, 2008.

17. Masala S, Anselmetti GC, Muto M, Mammucari M, Volpi T and Simonetti G: Percutaneous vertebroplasty relieves pain in metastatic cervical fractures. Clin Orthop Relat Res 469: 715-722, 2011.

18. Tseng YY, Lo YL, Chen LH, Lai PL and Yang ST: Percutaneous polymethylmethacrylate vertebroplasty in the treatment of pain induced by metastatic spine tumor. Surg Neurol 70: 78-83, 2008.

19. Cho DC and Sung JK: Palliative surgery for metastatic thoracic and lumbar tumors using posterolateral transpedicular approach with posterior instrumentation. Surg Neurol 71: 424-433, 2009.

20. Sciubba DM, Gokaslan ZL, Black JH III, Simmons O, Suk I, Witham TF, Bydon A and Wolinsky JP: 5-Level spondylectomy for en bloc resection of thoracic chordoma: Case report. Neurosurgery 69: E248-E256, 2011. 